\title{
The Effect of Glycerol Plasticizer Concentration on Physical-Chemical Characteristics of Edible Film from Catfish Skin Gelatin (Pangasius sp.)
}

\author{
Arga Bagus Prasetyo*, Eddy Suprayitno** \\ *Department of Fisheries Technology \\ Faculty of Fisheries and Marine Science \\ Brawijaya University, Indonesia \\ argabagus70@student.ub.ac.id \\ **Department of Fisheries Technology \\ Faculty of Fisheries and Marine Science \\ Brawijaya University, Indonesia \\ eddysuprayitno@ub.ac.id
}

DOI: 10.29322/IJSRP.11.10.2021.p11843

http://dx.doi.org/10.29322/IJSRP.11.10.2021.p11843

\begin{abstract}
Gelatin is a protein derivative compound extracted from animal collagen through hydrolysis and drying process. An edible film can be made from three different types of constituent materials, namely hydrocolloids, lipids, and composites of both. An edible film is an edible thin layer, which is formed to coat food components, and placed on top of or between the food components. One type of colloid that can be used to make the edible film is gelatin. A plasticizer is a substance with low molecular weight, that can enter the protein-polymer matrix, so it increases the flexibility and forming capability of the film. Glycerol is included as a type of plasticizer, which has a low molecular weight, is hydrophilic, adding polarity, and is easily soluble in water. The best edible film made from catfish skin gelatin was obtained at glycerol plasticizer concentration of $1.5 \%$ with physical and chemical characteristics including tensile strength of $6.22 \mathrm{MPa}$, elongation of $54.46 \%$, the thickness of $0.14 \mathrm{~mm}$, water vapor transmission rate of $189.45 \mathrm{~g} / \mathrm{m}^{2} / \mathrm{day}$, and water content of $10.46 \%$. The analysis results of the amino acid profile showed that the highest amino acid content of the edible film was glycine at $196518.28 \mathrm{mg} / \mathrm{kg}$, and the lowest amino acid content of the edible film was L-Tyrosine at $5370.36 \mathrm{mg} / \mathrm{kg}$.
\end{abstract}

Index Terms- gelatin, edible film, glycerol, amino acid profile

\section{INTRODUCTION}

Fish waste is a type of waste that has not been used optimally. Generally, the inedible portion of fish can reach $35 \%$. Whereas, there are skin and bones from fish waste that contain collagen. If it is processed further, it can produce gelatin (Ismail and Suprayitno, 2019). Fish skin that can be used as an alternative for making gelatin is catfish skin. Gelatin is a protein obtained from partial hydrolysis of collagen from skin, white connective tissue, and animal bones (Axiomawan and Suprayitno, 2019). Gelatin is a protein macromolecule that has functional properties and has been widely used in the pharmaceutical, food, and non-food fields. Gelatin has hydrocolloid properties, which can form a thin elastic layer, forming a transparent and strong film, and has high digestibility (Apriyani et al., 2020). Based on these properties, gelatin has the potential as a raw material for making an edible film.

The edible film is an edible thin layer, which is formed to coat food components, and placed on top of or between the food components. In food products, this thin layer serves to inhibit the transmission of water vapor and gas exchange, preventing loss of aroma and transferring fat, improving physical characteristics, as a carrier for additives, and also it is environmentally friendly (Miwada et al., 2015). The edible film, which is formed from a pure polymer, is brittle because of its low tensile strength. So, it is necessary to add plasticizer materials to increase its flexibility. A plasticizer is a substance with low molecular weight, that can enter the proteinpolymer matrix, so it increases the flexibility and forming capability of the film (Satriawan and Iling, 2017). The physical characteristics of the edible film are influenced by the types of materials and plasticizer concentration. Glycerol is included as a type of plasticizer, which has a low molecular weight, is hydrophilic, adding polarity, and is easily soluble in water (Prasetyo and Laila, 2018).

\section{MATERIALS AND METHODS}

\subsection{Material}


The research materials used consisted of materials for making gelatin, which were catfish skin obtained from PT. Dimas Reiza Perwira Surabaya, citric acid $\left(\mathrm{C}_{6} \mathrm{H}_{8} \mathrm{O}_{7}\right)$, aquadest, water, $\mathrm{pH}$ paper, aluminum foil, and calico fabric. The materials for making the edible film were catfish skin gelatin, aquadest, glycerol, and aluminum foil.

The method used in this study was the experimental method. The treatments used in this study were variations of glycerol plasticizer concentration. The experimental design used in this study was a Completely Randomized Design with 3 treatments and 6 replications. The glycerol plasticizer concentration used was $0.5 \%, 1 \%$, and $1.5 \%$.

\subsubsection{Making Gelatin}

The making of gelatin started with the preparation of the raw material, which was catfish skin. After that, the fish skin was soaked in warm water at $50^{\circ} \mathrm{C}$ for 30 minutes to remove dirt and remaining meat that was still attached. The clean fish skin was then weighed at $100 \mathrm{~g}$ and cut into small pieces of $1 \times 1 \mathrm{~cm}$. Furthermore, the fish skin was soaked using a $1 \%$ concentration of citric acid in a ratio of 1:3 (w/v) for 24 hours. When it was finished, the fish skin was rinsed using running water until the $\mathrm{pH}$ was neutral. Then, the fish skin was extracted with waterbath at $60-70^{\circ} \mathrm{C}$ for 6 hours. The ratio of catfish skin with distilled water was 1:3 (w/v). The next step was filtering the gelatin solution using calico fabric. After that, the obtained gelatin solution was poured into a baking pan. Then, a drying process was conducted using a dehydrator at $50-60^{\circ} \mathrm{C}$ for $8-12$ hours to dry. Furthermore, the resulting gelatin sheets were mashed using a blender and stored in a desiccator for further analysis.

\subsubsection{Making Edible Film}

The first thing to do in making the edible film was to prepare the catfish skin gelatin. Catfish skin gelatin was weighed at $5 \mathrm{~g}$ and then dissolved using $100 \mathrm{~mL}$ of distilled water. The gelatin solution was then heated by a hot plate at $60^{\circ} \mathrm{C}$ for 15 minutes and stirred using a magnetic stirrer. Then, the variation of glycerol concentration was added according to the treatment, which was $0.5 \% ; 1 \%$; and $1.5 \%$. After all the materials were mixed, it was stirred using a magnetic stirrer and reheated at $60^{\circ} \mathrm{C}$ for 15 minutes until homogeneous. After that, the mixture was poured into an $18 \times 18 \mathrm{~cm}$ baking pan. Then, the drying process was conducted by placing it in an oven at a temperature of $65^{\circ} \mathrm{C}$ for 18 hours. When it was finished, it was left at room temperature and was conducted the peeling process until the film took off from the baking pan. Furthermore, the film was stored in a desiccator and was ready for the test analysis.

\section{RESULT AND DISCUSSION}

\subsection{Tensile Strength}

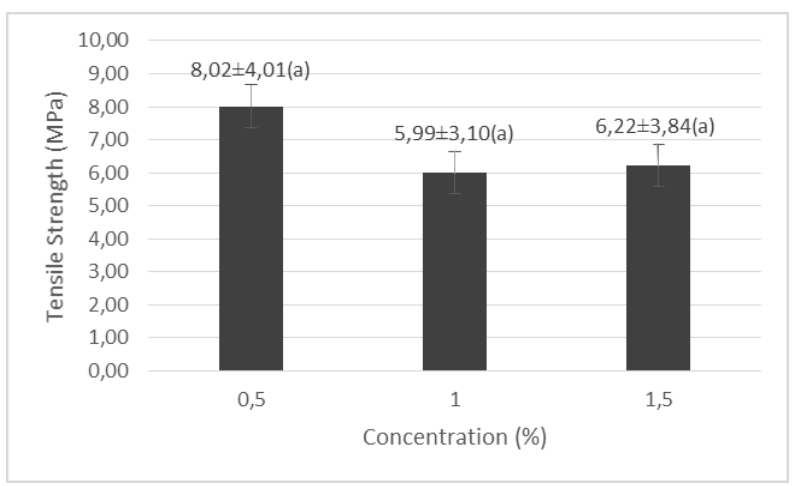

Figure 1. The Result of Tensile Strength

The tensile strength value of edible film with different glycerol plasticizer concentrations produced different tensile strength values. At glycerol plasticizer concentration of $0.5 \%$, it was obtained the tensile strength of $8.02 \mathrm{MPa}$, a $1 \%$ concentration was obtained of 5.99 MPa, and a 1.5\% concentration was obtained of 6.22 MPa. The highest tensile strength value of the edible film was obtained at glycerol plasticizer concentration of $0.5 \%$ with the tensile strength value of $8.02 \mathrm{MPa}$, and the lowest tensile strength value was obtained at glycerol plasticizer concentration of $1 \%$ with the tensile strength value of $5.99 \mathrm{MPa}$. Glycerol can reduce the interaction between molecules and weaken the tensile strength of the edible film, so it is obtained the elastic film (Wattimena et al., 2016).

\subsection{Elongation}




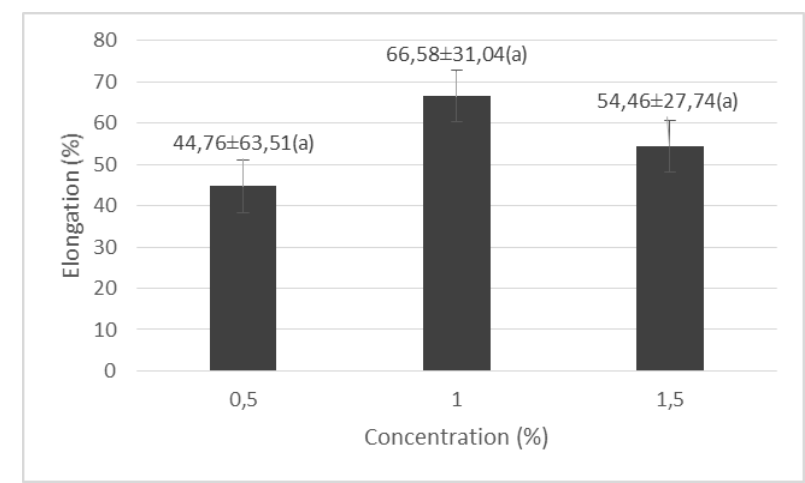

Figure 2. The Result of Elongation

Elongation value of edible film with the addition of glycerol plasticizer concentration of $0.5 \%$ was obtained of $44.76 \%$, a $1 \%$ concentration was obtained of $66.58 \%$, and a $1.5 \%$ concentration was obtained an elongation value of $54.46 \%$. The highest elongation value was obtained at glycerol plasticizer concentration of $1 \%$ with an elongation value of $66.58 \%$, and the lowest elongation value was obtained at glycerol plasticizer concentration of $0.5 \%$ with an elongation value of $44.76 \%$. According to Harianingsih et al., (2017), glycerol as a plasticizer can reduce internal hydrogen bonds by increasing the free space between molecules, so it reduces stiffness and increases film flexibility.

\subsection{Thickness}

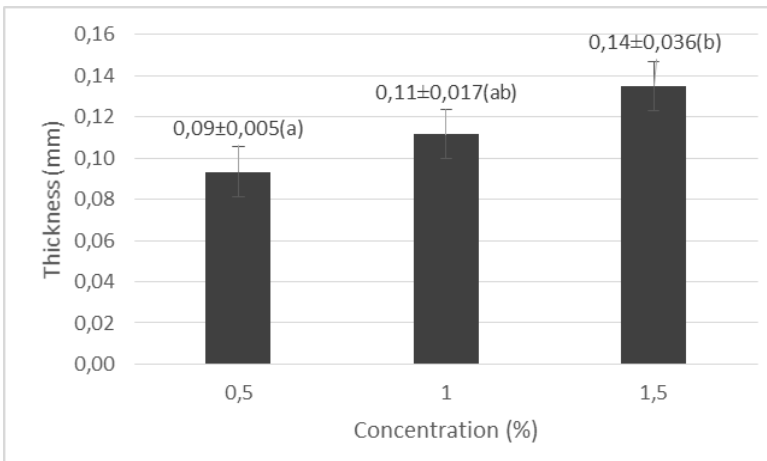

Figure 3. The Result of Thickness

Thickness value with different glycerol plasticizer concentrations produced different thickness values. At glycerol plasticizer concentration of $0.5 \%$, it was obtained the thickness of $0.09 \mathrm{~mm}$, a $1 \%$ concentration was obtained of $0.11 \mathrm{~mm}$, and a $1.5 \%$ concentration was obtained the thickness of the edible film of $0.14 \mathrm{~mm}$. The highest thickness of the edible film was obtained at glycerol plasticizer concentration of $1.5 \%$ with the thickness of $0.14 \mathrm{~mm}$, and the lowest thickness was obtained at glycerol plasticizer concentration of $0.5 \%$ with the thickness of $0.09 \mathrm{~mm}$. The thickness value of edible film showed an increase in glycerol plasticizer concentration given.

\subsection{Water Vapor Transmission Rate}

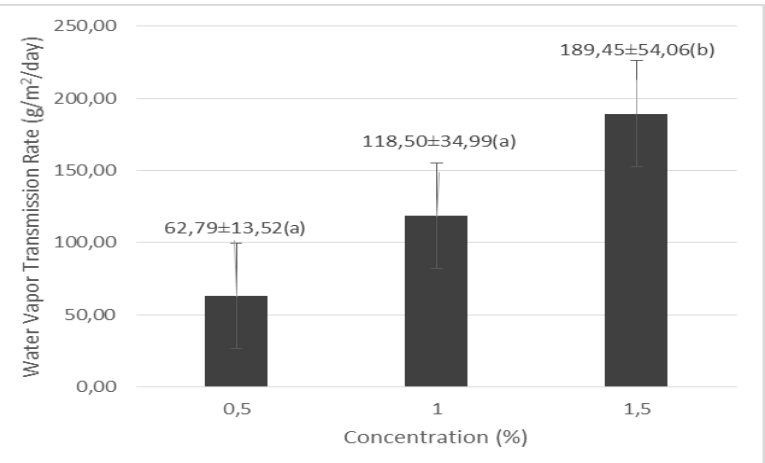

Figure 4. The Result of Water Vapor Transmission Rate

Value of water vapor transmission rate of the edible film with the addition of glycerol plasticizer concentration of $0.5 \%$ was obtained of $62.79 \mathrm{~g} / \mathrm{m}^{2} /$ day, a $1 \%$ concentration was obtained of $118.50 \mathrm{~g} / \mathrm{m}^{2} /$ day, and a $1.5 \%$ concentration was obtained of 189.45 $\mathrm{g} / \mathrm{m}^{2} /$ day. The highest value of water vapor transmission rate of the edible film was obtained at glycerol plasticizer concentration of 
$1.5 \%$ at $189.45 \mathrm{~g} / \mathrm{m}^{2} / \mathrm{day}$, and the lowest value of water vapor transmission rate was obtained at glycerol plasticizer concentration of $0.5 \%$ at $62.79 \mathrm{~g} / \mathrm{m}^{2} /$ day. Water vapor permeability is a measure of a material that can be passed by water vapor. The rate of water vapor transmission is influenced by factors, such as temperature, Rate Humidity (RH), the thickness of film, type and concentration of plasticizer, and the properties of basic materials of making the edible film (Utami et al., 2017).

\subsection{Water Content}

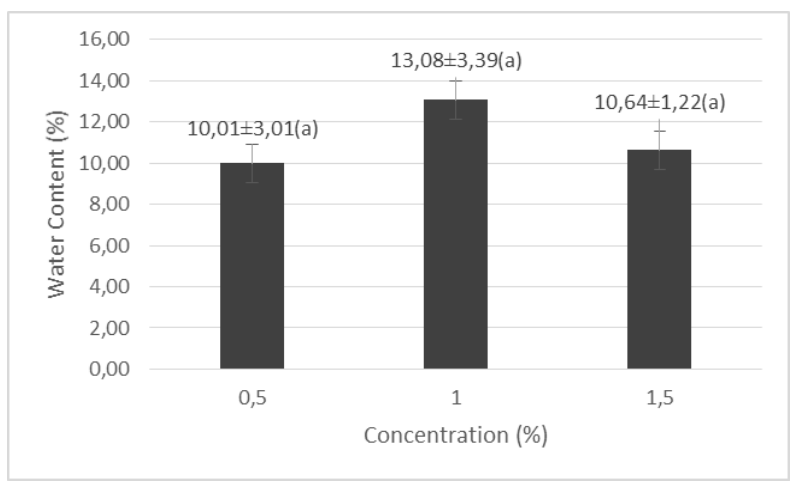

Figure 5. The Result of Water Content

The water content of the edible film with the addition of glycerol plasticizer concentration of $0.5 \%$ was obtained of $10.01 \%$, a $1 \%$ concentration was obtained of $13.08 \%$, and a $1.5 \%$ concentration was obtained the water content of $10.64 \%$. The highest water content value of the edible film was obtained glycerol plasticizer concentration of $1 \%$ with the water content of $13.08 \%$, and the lowest water content was obtained at glycerol plasticizer concentration of $0.5 \%$ with the water content of $10.01 \%$. According to Winarti et al., (2019), glycerol has the ability as a humectant that can bind water. When drying, the water is difficult to evaporate.

\subsection{Amino Acid Profile}

\begin{tabular}{clcr}
\hline No. & \multicolumn{1}{c}{ Parameter } & Unit & \multicolumn{1}{c}{ Result } \\
\hline 1 & L-Serine & $\mathrm{mg} / \mathrm{kg}$ & 35052.55 \\
2 & L-Glutamic Acid & $\mathrm{mg} / \mathrm{kg}$ & 75943.99 \\
3 & L-Phenylalanine & $\mathrm{mg} / \mathrm{kg}$ & 21015.26 \\
4 & L-Isoleucine & $\mathrm{mg} / \mathrm{kg}$ & 13970.43 \\
5 & L-Valin & $\mathrm{mg} / \mathrm{kg}$ & 22852.90 \\
6 & L-Alanine & $\mathrm{mg} / \mathrm{kg}$ & 81016.25 \\
7 & L-Arginine & $\mathrm{mg} / \mathrm{kg}$ & 84398.88 \\
8 & Glycine & $\mathrm{mg} / \mathrm{kg}$ & 230957.45 \\
9 & L-Lysine & $\mathrm{mg} / \mathrm{kg}$ & 35174.41 \\
10 & L-Aspartic Acid & $\mathrm{mg} / \mathrm{kg}$ & 37443.68 \\
11 & L-Leucine & $\mathrm{mg} / \mathrm{kg}$ & 28407.84 \\
12 & L-Tyrosine & $\mathrm{mg} / \mathrm{kg}$ & 5829.55 \\
13 & L-Proline & $\mathrm{mg} / \mathrm{kg}$ & 117204.43 \\
14 & L-Threonine & $\mathrm{mg} / \mathrm{kg}$ & 27911.79 \\
15 & L-Histidine & $\mathrm{mg} / \mathrm{kg}$ & 7746.23 \\
\hline
\end{tabular}

The amino acid profile can be detected in catfish skin gelatin. There were 15 types of amino acids. The highest amino acid content in catfish skin gelatin was glycine at $230957.45 \mathrm{mg} / \mathrm{kg}$, followed by L-Proline at $117204.43 \mathrm{mg} / \mathrm{kg}$, and the lowest amino acid was LTyrosine at $5829.55 \mathrm{mg} / \mathrm{kg}$. Catfish skin gelatin was then used as the main material in making the edible film. The amino acid profile of edible film is as follows.

\begin{tabular}{clcr}
\hline No. & \multicolumn{1}{c}{ Parameter } & Unit & Result \\
\hline 1 & L-Serine & $\mathrm{mg} / \mathrm{kg}$ & 30609.12 \\
2 & L-Glutamic Acid & $\mathrm{mg} / \mathrm{kg}$ & 69359.60 \\
3 & L-Phenylalanine & $\mathrm{mg} / \mathrm{kg}$ & 22135.10 \\
4 & L-Isoleucine & $\mathrm{mg} / \mathrm{kg}$ & 11515.19 \\
5 & L-Valin & $\mathrm{mg} / \mathrm{kg}$ & 18879.13 \\
6 & L-Alanine & $\mathrm{mg} / \mathrm{kg}$ & 70518.85 \\
7 & L-Arginine & $\mathrm{mg} / \mathrm{kg}$ & 76167.41 \\
8 & Glycine & $\mathrm{mg} / \mathrm{kg}$ & 196518.28 \\
9 & L-Lysine & $\mathrm{mg} / \mathrm{kg}$ & 22169.76 \\
10 & L-Aspartic Acid & $\mathrm{mg} / \mathrm{kg}$ & 37575.90 \\
\hline
\end{tabular}

This publication is licensed under Creative Commons Attribution CC BY. 


\begin{tabular}{lllr}
\hline 11 & L-Leucine & $\mathrm{mg} / \mathrm{kg}$ & 22990.44 \\
12 & L-Tyrosine & $\mathrm{mg} / \mathrm{kg}$ & 5370.36 \\
13 & L-Proline & $\mathrm{mg} / \mathrm{kg}$ & 93533.25 \\
14 & L-Threonine & $\mathrm{mg} / \mathrm{kg}$ & 24186.08 \\
15 & L-Histidine & $\mathrm{mg} / \mathrm{kg}$ & 7556.31 \\
\hline
\end{tabular}

Based on the best treatment, the amino acid profile can be detected on edible film from catfish skin gelatin. There were 15 types of amino acids ranging from $5370.36 \mathrm{mg} / \mathrm{kg}$ to $196518.28 \mathrm{mg} / \mathrm{kg}$. The highest amino acid content of the edible film from catfish skin gelatin was glycine at $196518.28 \mathrm{mg} / \mathrm{kg}$ and followed by L-Proline at $93533.25 \mathrm{mg} / \mathrm{kg}$ while the lowest amino acid of the edible film was L-Tyrosine at $5370.36 \mathrm{mg} / \mathrm{kg}$. The structure of edible film is dominated by amino acids which include $14 \%$ hydroxyproline, $16 \%$ proline and $26 \%$ glycine, this depends on the composition of gelatin contained in the raw material. Gelatin has a range strength, the special structure of gelatin contains hydroxylisin and hydroxyproline, which are amino acids that are not found in other proteins (Suprayitno, 2019).

Physical characteristics which was tensile strength of edible film influenced by the constituent components of the amino acids produced, especially the glycine and proline amino acids. This is in accordance with the statement of Hazirah et al., (2018), that glycine and proline amino acids play an important role in gel strength. Gelatin containing high amounts of glycine and proline amino acids has been shown to have high gel strength compared to gelatin with low glycine and proline amino acids. The higher of gelatin gel strength value used as raw material, the higher was the tensile strength value of the edible film.

\section{CONCLUSION}

The best edible film made from catfish skin gelatin was obtained at glycerol plasticizer concentration of $1.5 \%$ with physical and chemical characteristics including tensile strength of $6.22 \mathrm{MPa}$, elongation of $54.46 \%$, the thickness of $0.14 \mathrm{~mm}$, water vapor transmission rate of $189.45 \mathrm{~g} / \mathrm{m}^{2} /$ day, and water content of $10.46 \%$. The highest amino acid content of the edible film was glycine at $196518.28 \mathrm{mg} / \mathrm{kg}$, and the lowest amino acid was L-Tyrosine at $5370.36 \mathrm{mg} / \mathrm{kg}$.

\section{REFERENCES}

Apriyani, S.W., J. Sulistyorini and A.M. Nuryadi. 2020. Plastik edible berantioksidan yang diekstrak dari bawang hitam. Jurnal Penelitian Teknologi Industri. 12(1): 1-10. ISSN: 2614-4069.

Axiomawan, F. Y. and E. Suprayitno. 2019. The influence of acid type and extraction temperature on amino acid profiles and chemical physical characteristics of gelatin snapper fish bone. IOSR Journal of Agriculture and Veterinary Science (IOSR-JAVS). 12(5): 57-61. ISSN: 2319-2372.

Harianingsih., Suwardiyono and R. Wulandari. 2017. Pengaruh penambahan gliserol terhadap tensile strength dan elongation at break edible film dari nata de soya. Jurnal Inovasi Teknik Kimia. 2(1): 15-18. ISSN: 2541-5890.

Hazirah, N. binti Che Wan., A.M. Nafchi and N. Huda. 2018. Tensile strength, elongation at breaking point and surface color of a biodegradable film based on a duck feet gelatin and polyvinyl alcohol blend. Asia Pacific Journal of Sustainable Agriculture Food and Energy (APJSAFE). 6(2): 16-21. ISSN: 2338-1345.

Ismail, S. and E. Suprayitno. 2019. The effect of variation of acetic acid concentration on characteristics of gelatin from milkfish skin (Chanos chanos). IOSR Journal of Agriculture and Veterinary Science (IOSR-JAVS). 12(5): 52-56. ISSN: 2319-2380.

Miwada, I.N.S., I.N. Simpen., M. Hartawan., A. W. Puger and N.P.L. Sriyani. 2015. Karakteristik gelatin dari kulit kaki ternak dan potensinya sebagai edible film. Majalah Ilmiah Peternakan. 18(3): 109-113. ISSN: 0853-8999.

Prasetyo, H. A. and F. Laila. 2018. Pemanfaatan gliserol dan pati sagu sebagai edible coating pada penyimpanan jeruk siam madu (Citrus nobilis). Jurnal Agroteknosains. 2(1): 158-168. ISSN: 2598-0092.

Satriawan, M. B. and I. Illing. 2017. Uji ftir bioplastik dari limbah ampas sagu dengan penambahan variasi konsentrasi gelatin. Jurnal Dinamika. 8(2): 1-13. ISSN: 2503-4863.

Suprayitno, E. 2019. Amino acid marshmallow profile from grouper bone gelatin. International Journal of Scientific and Research Publications. 9(11): 111-113. ISSN: 2250-3153.

Utami, R., L.U. Khasanah., K.K. Yuniter and G.J. Manuhara. 2017. Pengaruh oleorisin daun kayu manis (Cinnamomun burmanii) dua tahap terhadap karakteristik edible film tapioka. Caraka Tani Journal of Sustainable Agriculture. 32(1): 55-67. ISSN: 08543984.

Wattimena, D., L. Ega and F.J. Polnaya. 2016. Karateristik edible film pati sagu alami dan pati sagu fosfat dengan penambahan gliserol. AGRITECH. 36(3): 247-252. ISSN: 0216-0455.

Winarti, S., Murtiningsih and F.N. Listyawati. 2019. Karakteristik mie merah gluten free dari tepung gadung (Dioscorea hispida Dennst) dan tepung mocaf dengan penambahan gliserol. Jurnal Teknologi dan Industri Pangan. 3(2): 135-143. ISSN: 2579-4523.

This publication is licensed under Creative Commons Attribution CC BY.

http://dx.doi.org/10.29322/IJSRP.11.10.2021.p11843

www.ijsrp.org 